Tekşan, M. ve Tekşan, K. (2015) Nazım Hikmet ve Yavuz Bülent Bakiler'in şiirlerinde kullandıkları kelimeler. Ana Dili Eğitimi Dergisi, 3(3), 20-50.

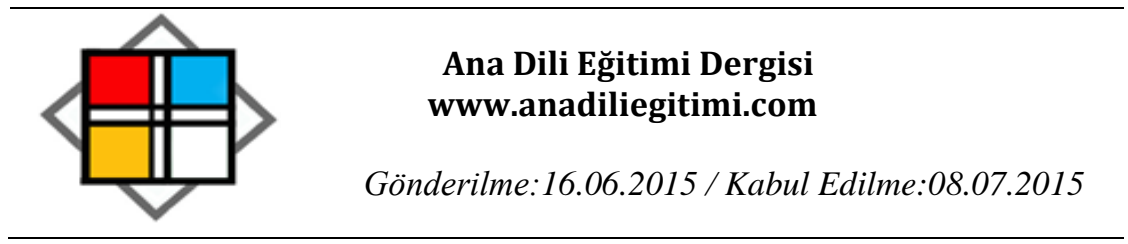

\title{
Nazım Hikmet ve Yavuz Bülent Bakiler'in Şiirlerinde Kullandıkları Kelimeler
}

\author{
Mesut TEKŞAN* \\ Keziban TEKŞAN ${ }^{+* *}$
}

\begin{abstract}
Öz
İnsanlar kelimelerle düşünürler, dünyayı kelimeler yoluyla anlamlandırır. Bundan dolayıdır ki duygu ve düşüncelerin açığa çıkması için kelimeler şarttır. Dil; insanın kişiliğini yansıtan, onu gösteren ayna olarak kabul edilir. Bu ayna onun tüm evrenle olan ilişkilerini de düzenler. İnsan evreni dilinin penceresinden görür ve gösterir. Bu durum şairler için çok daha anlamlıdır. Çalışmada yaşadıkları zaman ve dünya görüşleri farklı iki şairin Nazım Hikmet ve Yavuz Bülent Bakiler' in şiirlerinde kullandıkları kelimeler incelenerek farklılık ve benzerlikler tespit edilmiştir. Şairlerin kullandıkları kelimelerin büyük oranda farklılık gösterdiğini söylemek mümkündür. Fark, şairlerin siyasi düşüncelerinin farklı olmasından ve onların kendi düşüncelerini yansıtan kelimeleri özellikle kullanmasından ileri gelmiştir. Ayrıca şairlerin yetiştikleri ortamın ve beslendikleri kaynakların farklı olması ve gezip gördükleri yerler de kullandıkları kelimeleri farklı kılmıştır. Bunun yanında her iki şairin kullandığı ortak kelimeler de vardır. Ancak şairler için bu kelimelerin çağrışım değerleri farklılık göstermektedir. Şairlerin kullandıkları veya kullanmadıkları kelimelere bakarak onların dünya görüşlerini belirlemek mümkündür denilebilir.
\end{abstract}

Anahtar sözcükler: Nazım Hikmet, Yavuz Bülent Bakiler, kelime, şiir

\section{The Words Used in the Poems of Nâzım Hikmet Ran and Yavuz Bülent Bâkiler}

\begin{abstract}
Human beings reason and make sense of the world by means of the words. In this regard, words are prerequisites for the emergence of the feelings and thoughts. Therefore, language is assumed as a mirror reflecting the personality of a person and makes it visible. This mirror also organizes his relationships with the whole universe. People perceive and present the universe via languages. This situation makes more sense for the poets. In this research, the words in the poems of Nâzım Hikmet Ran and Yavuz Bülent Bâkiler, who live in different time periods throughout their lives and have different paradigms, were analyzed and similarities and differences between them were determined. The results show that the words used by two poets differ greatly. This variation is probably caused by their unlike political views and because of that they especially use the words reflecting these views. In addition, the dissimilar environments they grew up, lived, and experienced and different places they travelled affected the words they used. On the other hand, there are some common words used by these two poets as well. However, these words differ in terms of their associational meanings. As a result, it might be inferred that it is possible to determine the poets' paradigms by analyzing the words they used and the ones they did not use.
\end{abstract}

Keywords: Nâzım Hikmet Ran, Yavuz Bülent Bâkiler, words, poem

\footnotetext{
*Yrd.Doç.Dr., Ordu Üniversitesi, Fen Edebiyat Fakültesi, Türk Dili ve Edebiyatı Bölümü, Ordu.

** Doç.Dr., Ordu Üniversitesi, Eğitim Fakültesi, Türkçe Eğitimi Bölümü, Ordu. E-posta: kezibanteksan@gmail.com
} 


\section{Giriş}

Her gün kullandığımız kelimeler basit birer işaret değil duygu ve düşüncenin dile dönüşmüş şeklidir çünkü insanlar kelimelerle düşünürler. Bu bakımdan duygu ve düşüncelerin dille ifade edilmesi için kelimeler şarttır.Insanın dünyayı anlamlandırması kelimeler yoluyla gerçekleşir. Kişinin dili ne kadar zengin, kelime dağarcığı ne kadar geniş olursa düşüncesi de o ölçüde zengindir. Yani dil insanın kişiliğini yansıtan, onu gösteren bir aynadır. Zeynep Korkmaz "İnsan zekâsının, insandaki sınırı çizilemeyen duygu ve düşüncelerin ürünleri kendi benliğinin dışına dille aktarıldığına göre, dil ile düşünce iç içe girmiş durumdadır. Karşılıklı ilişkiler açısından bunları birbirinden ayırmak mümkün değildir. Konuşmalarımız ve sözlerimiz, daha doğrusu dilimiz, bir bakıma düşünce ve duygularımızın dışa uzanmış görüntüleridir." (Korkmaz,1995:662) diyerek dil düşünce ilişkisini vurgular. Emin Özdemir de “ínsanoğlunun dille bağlantısı sözcükler düzeyinde gerçekleşir. Dil toplumsal bir kurumdur ama sözcükler bireysel. Çağdaş dilbilimin ortaya koyduğu bir gerçektir bu. Acılarımızı, sevilerimizi, duygularımızı ve tasarılarımızı sözcüklerin aracılığıyla dışlaştırırız. Denilebilir ki sözcükler yön verir yaşamımıza” (Özdemir, 1973: 131) derken; dilin gücünü anlaşma aracı olmanın ötesinde gören Nermi Uygur da bu gücü; “Dil yalnızca insanı insana yaklaştıran, insanları değişik yönleriyle birbirlerine bağlayan bir yol değildir. Dil, insanın tüm evrenle karşılaşmasıdır. Tek tek gerçekler, nesneler, durumlar, olaylar, kuruluşlar, olanaklar hep bu karşılaşmada kendisini açığa vurur. Adlandırarak evreni biçimler, düzenler, dilce yeniden kurar dil. Evren dile getirdiği kılıkta vardır insan için. Böylece dil, evreni insana açar, insanın evrenin içine sokulabilmesini gerçekleştirir. Insanın her çevrildiği şeyle bağ kurması, ne çeşitten olursa olsun yaşantılarına konu olabilen bir şeyle bağ kurması dilin başarısıdır" (Uygur, 2001: 68) sözleriyle dile getirir.

Şüphesiz dili en iyi kullanan sanatçılardır ya da öyle olmaları beklenir. "Yazarlık da ozanlık da bir dil işçiliğidir her şeyden önce. Yazarlık, dil işçiliğidir dedik. Bu, dilin olanaklarını tanıma, bunları en uç noktasına değin işletmedir. Daha doğrusu sanatçının her yaratısında dili yeniden kurması, yeniden yaratmasıdır. Sesleri, sözcükleri, sözcüklerin bağlaşım ve sözdizimini yoklaması; onlardaki incelikleri, gizli güzellikleri bulup ortaya çıkarmasıdır" (Özdemir, 1973: 10). Dolayısıyla şairlerin şiirlerinde kullandıkları kelimelerle hayatları, duygu ve düşünce dünyaları arasında çok kuvvetli bir etkileşim vardır.

Dil hem insanlığa verilen en büyük nimetlerin başında gelmekte hem de insanları diğer varlıklardan ayırmaktadır. Düşünen ve duyan insanın Görüldüğü gibi düşünce ve duyguların aktarımını sağlayan kelimeler insanlar için önemlidir. Bu araştırmanın amacı da yaşadıkları zaman ve dünya görüşleri farklı iki şairin, Nazım Hikmet Ran (17 Ocak 1902- 03 Haziran 1963) ve Yavuz Bülent Bakiler (23 Nisan 1936-...) 'in, kullandıkları kelimeleri tespit etmek ve bu yolla dünyayı nasıl algıladıklarını belirlemektir. Bu kelimeleri belirlemek ayrıca sanatçıların daha çok hangi temaları ele aldıklarının belirlenmesine de yardımcı olacaktır. 


\section{Nazım Hikmet'in Şiirlerinde Kullandığı Kelimeler}

Nazım Hikmet kimilerine göre; Türk dilini yücelten, memleketini çok seven, Türk sanatını yeryüzünde haysiyetli bir yörüngeye oturttuğu için büyük vatan şairidir; kimilerine göre de sadece bir şair değil, gençlik yıllarından beri Moskova'ya bağlı, onun emrinde çalışan, Türkiye'nin bir Sovyet peyki olmasını isteyen bir ihtilâlcidir. Mehmet Kaplan "Kurtuluş Destanı'nı yazması veya başka şiirlerinde Türkiye'yi ve Türk halkını sevmesi beni ikna etmiyordu. $\mathrm{O}$, İstiklâl Savaşı'na Türk milletinin inandığı zaviyeden bakmadığı gibi, sosyal problemleri de milli duygularla ele almıyordu" (Kaplan, 1980: 345) derken Kadri Timurtaş, "Büyük şair olmayan Nazım Hikmet, 'Vatan şairi' hiç değildir" diyerek görüşlerini şöyle sürdürür: "Vatan şairi vatanını iyi veya kötü günlerinde onunla hemhâl olan şairdir. İstiklâl Savaşında emsali vatan için dövüşürken Rusya'ya kaçıp Moskova'da komünistlik ve ajanlık tahsil (!) eden bir adam nasıl vatansever ve vatan şairi olabilir? Hapisten çıktıktan sonra durumu iyi iken, yurttan firar eden ve Moskova hava alanında "Ben Sovyetler Birliği'nin çocuğuyum. Şimdi asıl vatanıma kavuştum. Beni Stalin yarattı" diyen adam vatan şairi kabul edilebilir mi?" (Timurtaş, 1997: 70).

Bu çalışmada "Vatan şairi" veya "Vatan haini" olarak iki uçta yapılan değerlendirmeden farklı olarak Nazım Hikmet, şiirlerinde kullandığı kelimeler ve dil politikası bağlamında değerlendirilecektir. Çünkü o VâNû'nun hatıralarında belirttiği gibi "Türkçeye bağlı kalmıştır". "Nazım Hikmet her şeyi inkâr etmiş olsa bile Türkçeye bağlı kalmıştır. Eserlerini Türkçe yazmıştır. Onlar bir vakıa olarak mevcutturlar" (Kaplan, 1980: 346).

Moskova'ya gitmeden önce de şiirler yazan Nazım Hikmet, bu şiirlerinde vatanın içinde bulunduğu kötü durumdan duyduğu acı ve endişeleri dile getirmiştir. Bu şiirlerinde seçtiği kelimeler de vatan ve milletle ilgili kelimelerdir.

"Ey zavallı vatanım

Neden böyle ağlıyor

Neden midir, çünkü ona

Evlatları bakmıyor

Oğul- Bakmaz isem ben sana

Haram olsun Türklük bana

İşte ona gidiyoruz

Vatan için ölmeye

Gidiyorum öleceğim

Dönmeyeceğim geriye" (Ran,1995h: 13) 
Yukarıdaki şiirde görülen "vatan- anne" imajı Namık Kemal'i hatırlatır. Mevlevi tarikatı mensubu olan dedesi Mehmet Nazım Paşa'nın terbiyesinde büyüyen şair, başlangıçta dinin kutsallarına karşı hassastır ve bu hassasiyetini kelimelerine de yansıtmıştır.

" Havsalam almıyor bu hazin hâli önce

Ah, ey zavallı cami, seni böyle görünce

Dertli bir çocuk gibi imanıma bağlandım;

Allah'ımın ismini daha çok candan andım." (Ran, 1995a: 117)

Şairin dini inancı daha sonra sarsılmaya başlar. Moskova'ya gittiğinde o artık kutsal değerlere olan inancını iyice kaybetmiştir. Şair, Kastamonu'da dini inançlara oldukça mesafeli bir dünya görüşü olan komünizmle tanışmış ve bu görüşü benimsemiştir.(Kaplan,1980:357). Bu benimseyişle Nazım, hayatını ve sanatını Moskova'nın emrine vermiş ve bundan sonra yazdığı şiirlerinin kelime kadrosunda dikkat çekici değişmeler olmuştur. Bu anlayışla yazdığı şiirlerinde Lenin, Marks, Engels, 1 Mayıs, işçiler, grev, yoldaş, patron... gibi kelimeler daha sık görülmeye başlanır.

"Seslenin seslenebildiğiniz kadar

Ses-

-lenin

24 saatta 24 saat Lenin,

24 saat Marks

24 saat Engels,

yüz dirhem kara ekmek" (Ran,1995a: 216)

"Düşmanı yenecek işçi sınıfımıza selâm!

Paranın padişahlığını

karanlığını

ve yabancının roketini yenecek iş̧̧i sınıfına selâm!"(Ran, 1995g: 147)

" SSSR

gidiyoruz artık,

ver elini ver,

vedalaşalım!

Sevdik,

Seviyoruz seni,

nasıl severse kurşun yaralı duvarların 


\section{Marks'ın resmini!}

Müjiklerin toprağı sevdiği kadar

sevdik

seviyoruz

seni!" ( Ran,1995h: 210)

$" \ldots$

Insanların en büyüğü Engels...

Vladimir İliç Ulyanof Lenin

ateşten bir dev gibi çıktığı zaman

barikada"

şair şiirin devamında kendi ideolojisini belirler:

"Bana gelince

Ben ki, herhangi bir proleter şairiyim,

Marksisto- Leninist şuur" (Ran,1995b: 101)

Kendisinin de belirttiği gibi o artık herhangi bir proleter şairdir. Dolayısı ile artık şiirlerinde diğer proleter şairlerin işlediği konular ve kullandığı kelimeler vardır. Yukarıdaki şiirlerde görüldüğü gibi Nazım, ideolojisini yaymak için şiiri ihmal etmiştir. Kürsüde konuşan bir siyasetçi gibi heyecanlara seslenir.

Komünizmde vatan yerine beynelmilellik yani bütün dünya iş̧̧ilerinin birliği vardır. Nazım'ın şiirlerinde de Hintli 'den İngiliz'ine, Rus'undan Amerikalısına her milletten insan isimleri yer alır:

“Orası

Sayın halkları bütün ırkların,

Endonezyalısı, Almanı, Eskimosu,

Sudanlısı, Çinlisi, Türkü, Ermenisi,

Yahudi'si, Arabı, Lehlisi, Rus'u,

Meksikalısı, Norveçlisi, Kırgız'ı,

Abhazyaları, Hintlisi, Kürdü, Fransız'ı,

Farsı, Liberyalısı, İngiliz'i,

Amerikalısı: ak, kara, kırmızı,

tükenir mi saymakla

ve adını duymadıklarım,

hepinizi, hepinizi 
yerlere kadar eğilerek selâmlarım

$\cdots$

"Oralı ilk yeni adamı yüzyılımın, bütün yurtlarımın yurttaşı Lenin Yoldaş" (Ran, 1995e: 163)

" ve Gagarin Yoldaşın ve daha adını sanını kaşını gözünü

bilmediğimiz Titof Yoldaşın ve ondan sonrakilerin ve tavan arasında yatan

genç kadının

Küba'dan döndüm bu sabah

Küba meydanında altı milyon kişi akı karası sarısı,

melezi ışıklı bir" (Ran,1995g: 77)

Bir şiirinde;

"Sen şiirin asil konusuyla konuşuyorsun,

ben asaletten anlamam

Şapka çıkarmam konuştuğun dile,

düşmanıyım asaletin

Kelimelerde bile." diyen şair, açlık, yoksulluk, kan,

kızıl gibi kelimelere benimsediği ideolojinin terminolojisini çağrıştıran özel anlamlar yükler.

"Ne erkek, ne kadın, ne oğlan, ne kız

açlar dizilmiş açlar!

Bunlar!

yüreğin parçaları

o kurak

toprakların!

Kimi

kemik

dizlerine vurarak

yuvarlak

bir karın

taşıyor!" (Ran,1995a: 25)

"Biz

Çıplak ayaklı Hindistan'ın açlığını

esmer gözlerinde bir alev gibi taşıyanlar." (Ran,1995b: 119)

"Daha gün o gün değil, derlenip dürülmesin bayraklar 
Dinleyin, duyduğumuz çakalların ulumasıdır.

Safları sıklaştırın çocuklar,

bu kavga faşizme karşı, bu kavga hürriyet kavgasıdır" (Ran,1995g: 10)

İdeolojisi nedeniyle hapse atılan şair, Türk köylüsünü hapishanede tanıma fırsatı bulmuştur.

"Kelleci Memed'i hatırlıyor musun?

Sübyan koğuşundan.

Başı dört köşe,

bacakları kısa ve kalın

ve elleri ayaklarından büyük.

Kovanından bal çaldığı adamın taşla ezmiş kafasını” (Ran,1995e: 145)

Bütün bunların yanı sıra o Anadolu insanının açlığını da ele alır. Fakat Anadolu insanının açlığını onlarla beraber yaşayarak göremez de gazete sayfalarından öğrenir; çünkü artık memleketten uzaktadır.

Dışardan bakıldığında da memleketin durumu çok da parlak değildir. Bu da onun ideolojisini yaymak ve halkın içinde bulunduğu durumu şiirine yansıtmak için bir fırsat olmuştur. "Kara Yara" adlı şiirinde Anadolu insanı ile yönetenler arasındaki uçuruma ironik bir bakışla dikkat çekmiştir.

"Birinci sayfada yatıyor iki sütun üstüne

iki çıplak yavrucuk

birinci sayfada iki sütün üstüne

bir avuç kemik deri.

Delinmiş patlamış etleri.

Biri Diyarbakırlı, Erganili biri.

Kolları bacakları kargacık burgacık,

Ve işte Emniyet Müdürü Bey

Uçaktan iniyorlar

Amerika'dan dönüyorlar

mesleki tetkikattan" (Ran,1995g: 23)

Şaire göre komünizmin baş düşmanı Amerika ve İngiltere'dir, kapitalizmdir, Almanya'dır ve faşizmdir. İşçileri ezen patronlardır. Bu nedenle Nazım'ın şiirlerinde bu kelimeler hep kötü, acımasız, zulmeden, insanları sömüren, öldüren bir düşman gibi gösterilmiştir. 
"...

Gittiğimiz sinemanın

üç kapısı var:

Birincinin önünde:

otomobiller tepiniyor,

farklı Britanya bankaları iniyor,

ikincinin önünde:

küçük dar

dükkânlarla

dar

tarlalar.

üçüncü kapı bizim,

ordan

biz giriyoruz,

istihsal aletinden mahrum olanlar.

içerde

the polismenler gösteriyor yerlerini

müşterilerin:

- Buyurun siz oturunuz!

oturdular

- Oturun!

oturdular

- oturun ulan kerata...

oturduk

Lambalar söndü.

Muzıka başladı, makina döndü.

Perde de

İkinci kısmın ismi göründü:

"Hindistanlı Parya

VE PROLETARYA..."

The polismenler el attı kıçlarına.

Birinci mevki homurdandı. 
İkinci sallandı.

Bağırdı üçüncü mevki

avazı çıktığı kadar" (Ran,1995b: 52)

Uzun yıllar Rusya'da yaşayan ve orada ölen şairin şiirlerinde doğal olarak Rusça isimler ve Rusça kelimeler sıkça kullanılmıştır. Nazım bu isimleri sanki bizden birinin isimleri gibi kullanmaktadır.

$" \ldots$

Gitmek Moskova'ya bir kerecik, bir günlüğüne.

Daha çok kalamam şimdilik.

Ne Bolşoy'da bale, ne Lujniki'de futbol, ne Dubna'da tanışmak atom reaktörüyle, gitmek Moskova'ya bir günlüğüne

Kremlin'de İliç'in

Odasını görmek için.

Gitmek Moskova'ya bir günlüğüne.

Daha çok kalamam şimdilik.

geçmek Kızıl Meydan'ı

1 Mayısta bir kerecik" (Ran,1995g: 179)

$" \ldots$

toprak gibi ihtiyarları vardı, toprak gibi akıllı uslu.

Tek kelime Rusça bilmezdi çoğu

Haraşo'dan başka, belki de Tavariş.

$\cdots$

Ben eski Moskovalıyım eski İstanbullu olduğum kadar.

Krasnaya Presya'da bir fabrika var, orda çıktım ilk defa huzura.

Rüyalarının memleketi olan, beyaz şehir olan Moskova.

"en kutsal umudumuzun ağacı 
Lenin'in memleketine dikildi" (Ran,1995a: 193)

Nazım kendini "eski İstanbullu olduğu kadar da eski Moskovalı” hissetmektedir. Ona göre Rusya, Lenin'in memleketi ve komünizmin beşiğidir. Bu nedenle olsa gerektir ki şiirlerinde en çok Rusya ile ilgili kelimeleri kullanmıştır. Dünyaya da hep Moskova penceresinden bakmaktadır. Bununla beraber onun şiirlerinde Doğu bloğu ülkelerinin isimleri de çok geçer. Çünkü Nazım Moskova'ya gittikten sonra devamlı o ülkeleri gezmiştir. Mesela Prag, Varna, Sofya, Kief, Çabi, Yanoş, ... vb.

Komünizme candan inanmış şairin şiirlerinde Amerika, İngiliz ve Alman düşmanlığı dile gelir. $" \ldots$

BiRiNCI POLiS- Köprünün üstünde

bir Hintli karı gördüm demin.

Kucağında kertenkele suratlı bir çocuk vardı.

Çocuk beni görünce başladı ağlamaya

$$
\text { ağlamaya }
$$

ağlamaya...

Karıya:

- Sustur şu piçi,

Biritanya polisine selam versin,

$$
\text { dedim }
$$

Selâm vermezse, kuyruksuz bir fare gibi

gebersin

dedim.

Ne sustu, ne selam verdi kara kurbağa yavrusu

Akıyordu su...

Akarsuya fırlattım bu zırlayan şeytan piçini.

$\cdots$

Birinci Polis- Grevde yakalanan

Hintlilerden birinin

taze kesilmiş başparmağı...

Kesildikten sonra yarım santim uzadı tırnağı..." (Ran,1995b: 35-37)

Onun şiirlerinde Kalkütalı, Hintli, Mısırlı, Portsaidli, Japonyalı delikanlılar, çocuklar, kadınlar, işçiler ve acılı Borneo, Sumatra ve Cava köylüleri merhamet bulur. Bilhassa Japonya özel bir yer teşkil eder. Çünkü 
Amerikan emperyalizmi orayı yerle bir etmiştir. Nazım, şiirlerinde atom bombasından "bulut" diye bahsetmektedir:

$" \ldots$

Koşuyor altı yaşında bir oğlan,

uçurtması geliyor ağaçlardan,

siz de böyle koşmuştunuz bir zaman.

çocuklara kıymayın efendiler.

Bulutlar adam öldürmesin." (Ran,1995f: 54)

" Denizde bir bulutun öldürdüğü

Japon balıkçısı genç bir adamdı

Dostlarından dinledim bu türküyü

Pasifikte sapsarı bir akşamdı" (Ran,1995f: 80)

"Hiroşima'da öleli

oluyor bir on yıl kadar.

Yedi yaşında bir kızın,

büyümez ölü çocuklar." (Ran,1995f: 81)

$" .$.

uçak alanında sessiz pilotlar

"h" bombası yükler tepkililere

ve güneş doğarken, güneş doğarken

otomatik silahlarla biçilir

üniversitelilerle işçiler

$\cdots$

Ve güneş doğarken devlet adamı

konağına döner bir ziyaretten." (Ran, 1995f: 137)

Nazım Amerika'nın Türkiye'deki etkisinden de rahatsız olur:

"Hapse atacaklarmış Ahmet Emin Yalman'ı

Amerikan'a yaranmaktaki rekabet yüzünden,

Hapisteki hırsızlara acıyorum ben,

ahlâkları bozulacak." (Ran, 1995g: 25) 
"...

Ve işte Emniyet Müdürü Bey

uçaktan iniyorlar

Amerika'dan dönüyorlar

mesleki tetkikatten" (Ran,1995g: 23)

"Eli kolu zincirlere vurulmuş,

vatan çırılçıplak yere serilmiş.

Oturmuş göğsüne Teksaslı çavuş.

Beyler bu vatana nasıl kıydınız?" (Ran, 1995g: 8)

Nazım'ın şiirlerinde Amerikan düşmanlığını ve Rus hayranlığını yansıtan kelimeler yan yana yer alır.

"Kosmosta bizden başka düşünen var mı?

$\cdots$

yıldızlardan birinde konuşacak elçimiz onunla

Tovariş diyecek

söze bu sözle başlayacak biliyorum

Tovariş diyecek

ne üs kurmağa geldim yıldızına

ne petrol ne yemiş imtiyazı istemeye

Koka-kola satacak değilim." (Ran,1995g: 65)

Amerikan zulmünden en çok etkilenen kesim şüphesiz zencilerdir. Nazım, şiirlerinde bu konuyu da dile getirir.

" Afrika, Niyazalant sömürgesi.

Saat sabahın dördü.

Dipçikler kapıları dövdü

ve işte fotoğraf:

Zenci kardeşlerim bir don bir gömlek

ve ayakları çıplak

ve pembe avuçlu elleri kıvırcık başlarının üzerinde

dizilmiş duvar diplerinde" (Ran,1995g: 108) 
Nazım'ın son şiirlerinde memleket hasreti çektiği açıkça görülür. Kimi zaman Anadolu kimi zaman İstanbul veya evlat olur hasretinin adı.

"Memleketim, memleketim, memleketim,

ne kasketim kaldı senin ora işi,

ne yollarını taşımış ayakkabım,

son mintanın da sırtımda paralandı çoktan,

Şile bezindendi.

Sen şimdi yalnız saçının akında, enfarktında yüreğimin, alnımın çizgilerindensin memleketim,

memleketim,

memleketim..." (Ran,1995e: 139)

"Anadolu'm, ah Anadolu'm,

belki bir mezar boyu uzaksın benden" (Ran,1995g: 140)

"içinde acısı var yemişi koparılmış bir dalın,

gitmez gözümden hayali Haliç'e inen yolun,

iki gözlü bir bıçaktır yüreğime saplanmış

evlat hasretiyle hasreti İstanbul'un" (Ran,1995f: 49)

"ben dilimden, türkülerimden,

tuzumdan, ekmeğimden uzakta,

anana hasret, sana hasret" (Ran,1995f: 52)

Türkülerimize bile hasret duyan şair memleketi fakir görür:

" Memleketler içinde bir şirin memlekettir

\section{Türkiye}

bizim memleket.

İnsanı da

su katılmamışı

çalışkandır, ağırbaşlı, yiğittir

ama dehşetli fakir." (Ran,1995f: 52) 
Memleketine, oğluna ve oğlunun annesine hasretliği ta yüreğinde duyan şair için türkü, insanı anlamanın bir anahtarıdır.

" İnsanların türküleri kendilerinden güzel, kendilerinden umutlu, kendilerinden kederli, daha uzun ömürlü kendilerinden.

Serdim insanlardan çok türkülerini.

insansız yaşayabildim

türküsüz hiçbir zaman.

Hiçbir zaman aldatmadı türküler de.

Türküleri anladım hangi dilde söylenirse söylensin.

Bu dünyada yiyip içtiklerimin, gezip tozduklarımın görüp işittiklerimin, dokunduklarımın, anladıklarımın hiçbiri, hiçbiri, beni bahtiyar etmedi türküler kadar." (Ran,1995g: 58)

Nazım'ın şiirlerinde akrabalık ilişkilerini gösteren kelimeler sıkça kullanılmıştır.

" Sevgilim, dayı kızım, Mehmed'imin annesi, dedelerimizden biri 1848 Polonya muhaciri.

Belki o Varşovalı güzel kadına, senin ikizmişsiniz gibi benzeyişin bundandır belki ben bu yüzden bu ova bana bizim ovaları hatırlatıyor, yahut da bu yüzden bu Leh türküsü, içimde, derin, yarı aydınlık uyuyan bir suyu kımıldatıyor.

$\cdots$

Göğsümü kabartmıyor değil

dedelerimden birinin Lehli oluşu..." (Ran,1995f: 34)" 
Nazım Hikmet' in şiirlerinde aşk da önemli bir yer tutar. Her şair aşkı ele almıştır elbette ama Nazım da bu oldukça yoğundur. Bilhassa hapishanede yatarken onu ayakta tutan sevdiği kadındır. Hapishanede onu ziyaret eden ya da mektup yazan, affedilmesi için uğraşan kadın. Nazım'ın şiirlerinde kullandığı aşk kelimeleri her gün kullandığımız sıradan kelimelerdir, ama şair onlara anlamlar yükler.

" Hoş geldin, kadınım benim, hoş geldin!

Ayağını bastın odama

Kırk yıllık beton çayır çimen şimdi.

Güldün

güller açıldı penceremin demirlerinde.

Ağladın,

Avuçlarıma döküldü inciler;

gönlüm gibi zengin

hürriyet gibi aydınlık oldu odam." (Ran,1995d: 172)

" Karıcığım,

Hasretliğin on ikinci yılı bu

on ikinci yılı

Gönül ağzına kadar dolu

Sen diyorum İstanbul geliyor aklıma

İstanbul diyorum sen

Sen şehrim kadar güzelsin

şehrim senin kadar acılı" (Ran,1995d: 198)

Onun şiirlerinde çocuklar da özel bir yer tutar. Şiirlerinde bir Japon kız çocuğundan Port-Saidli Mansur'a kadar geniş bir çocuk kadrosu vardır.

"Port- Saidli Mansur'un on üç, on dört yaşında.

Yalnayak, başıkabak, oturur boya boyar

aynalı, çıngıraklı sandığının başında" (Ran,1995f: 87)

"Bir kız vardı Japonya'da

ufacık, tefecik bir kız.

$\cdots$

Bir bulut bu kızcağızın 
öldürdü nineciğini, külünü göğe savurdu, sonra, yine apansızın gelip babasını vurdu, sonra da kızın kendini" (Ran,1995g: 155) "Çocukların avuçlarında günlerimiz sıra bekler, günlerimiz tohumlardır avuçlarında çocukların, çocukların avuçlarında yeşerecekler. çocukların avuçlarında yeşerecekler." (Ran,1995g: 152)

Nazım, çocukların onunla samimiyetini bir ayrıcalık olarak görür.

"Sana bir şey söyleyeceğim, böbürleniyorsun, diyeceksin, ama hakikat:

Çocuklar çabucak ahbap oluyor benimle.

Hapishanede pencereme gelen kuşlar da öyleydi.

Ters anlama, Çocukları kuşlara filan benzettiğim yok.

Bilirsin ya, çocuklar, akıllı cesur mahlûklar" (Ran,1995f: 39)

Nazım ideolojisini dillendirdiği şiirlerinde çoğu zaman kürsüde haykıran bir hatip gibi konuşur. “Nazım bir hatiptir. Şiirleriyle daima kalabalıklara tesir etmeyi düşünür”(Kaplan,1980:359). Fakat aynı şair fikir endişesi gözetmediği şiirlerinde ise lirizmi yakalamış; hasretini, aşkını en güzel anlatacak kelimeleri seçmiştir. Bu şiirlerde kullandığı kelimelere bakarak da onun aşk şairi ve memleket hasreti çeken bir şair olduğunu söylemek mümkündür. Ancak Nazım daha çok ideolojik şiirleriyle tanındı. Buradan hareketle 'Nazım Hikmet sanatını ideolojisinin emrine vermiştir' denilebilir. Şiirlerinde kullandığı kelimeler onun ideolojisini yansıtır ve şiirlerde kullandığı kelimelere bakarak onun dünya görüşünü tespit etmek mümkündür

\section{Yavuz Bülent Bâkiler'in Şiirlerinde Kullandığı Kelimeler}

Azerbaycan'ın Karabağ şehrinin Ağdam köyünden Türkiye'ye göç etmiş bir aileye mensup olan Yavuz Bülent ise yetiştiği ortamda hep o yerlere duyulan özlemi dinlemiş, o yörelerin türküleriyle büyümüş 
ve hayatının en önemli sevdası o yöreler olmuştur. Kendisi de bunu şöyle belirtir: "Türkistan ve Azerbaycan, kendimi bildim bileli, benim karasevdamdır. Azerbaycan'ı önce anamın yanık türkülü masallar dünyası içinde tanıyıp sevdim". Şengül- Mengül- Küflengül Masalı'nda, Azerbaycan, kurnaz kurdun kaptığı ŞengülMengül'dü. Ben, bir tandır dibinde yapayalnız kalan Küflengül'düm. Türkistan'ı ise babamın ölünceye kadar hiç eksilmeyen bir ilgiyle takip ettiği, o çağlayanlar gibi coşkun ruhlu dergilerin ve kitapların sayfalarında tanıyarak büyüdüm” (Bakiler, 1992: 9).Yetiştiği ortamın şairi derinden etkilediği açıkça görülmektedir.

Şair için Türk kültür kaynaklarını sadece Anadolu'da aramak yanlıştır. "Çünkü bütün özellikleriyle Türkistan'ı ve Azerbaycan'ı bilmeden ve sevmeden, kültür davamızı tam manasıyla kucaklamamız mümkün değildir. Dilimizin, tarihimizin, destanlarımızın, sanatımızın, inançlarımızın, geleneklerimizin, oyunlarımııın... Kaynaklarını, sadece Anadolu'da aramak, kanaatime göre yarım kalmaktır" (Bâkiler, 1992: 15 ).

Bâkiler'in bu duyuş ve düşüncesi dil politikasına da yansımıştır. Onun şiirlerinde Türkiye dışındaki Türklere karşı büyük bir sevgi hasret ve merhamet bildiren kelimeler vardır. Türk vatanın sınırlarını Altaylardan Tuna'ya kadar çizen şairin şiirlerinde bu coğrafyanın isimleri sıkça kullanılır. Diyebiliriz ki şairin vatan sınırları genişledikçe kelime hazinesi de o kadar genişlemiştir ve bu vatanın sınırları "Altaylardan Tuna'ya " kadar uzanır:

" Yüzyıllardan beridir Altaylardan Tuna'ya

Bizim türkülerimizdir söylenen

Konuşulan dil, bizim dilimizdir

Renk renk, nakış nakış uzanan toprak değildir

Kilimlerimizdir... (Bakiler, 1991a: 61)

Bu coğrafyada "Azerbaycan yüreğimde bir şah damardır" dediği Azerbaycan- Karabağ kelimeleri sık sık geçer ve özel bir yer tutar:

" Adına el-pençe divan durduğum

Bin yıllık karasevdamız, ilahımız, ülkümüz.

Türküler söyleyerek içimde gece-gündüz

Bir çalar saat gibi kurduğum" (Bakiler, 1991b: 48) 
"Ben Yakup gibiyim uzun yıllardır

Onda Yusuf'unun kokusu vardır.

Ve hasreti, gönlümde, büyük Türkistan kadardır.

Âyettir kitabımda, bayrağımda rüzgârdır

Azerbaycan yüreğimde bir şah damardır." (Bakiler, 1991b: 51)

Şair " Öz yurdum" dediği Türkistan' a karşı büyük bir sevgi, hasret ve yanma derecesinde bir acı, bir merhamet duyar ve bunu yansıtan kelimeleri çokça kullanır.

" Öz yurdumu çarmıha germişler kırk yerinden

Bin yıl geçse unutmam, acının üzerinden

Vurulan bir ceylana yanar gibi derinden

Ulu Türkistan'a yandım.

Tanrım, bir gün acaba diyebilecek miyim?

Vuslatın yüzünü nakışladığı nurla

Bir komşu bahçesine uzanır gibi huzurla

Türkistan'ın toprağına uzandım (Bakiler,1991b: 53)

Kerkük Türklerine yapılan eziyetleri ta yüreğinde duyan şair bunu şiirlerine, diline de yansıtır.

" Bir gece Kerkük'te vurdular beni.

Geçti sokaklardan bir kızıl ordu.

İlâmı ve Türk'ü vuruyordu kurşunlar

Peygamber kabrinde ağlıyordu. (Bakiler,1991c: 60)

Şairin deyimiyle " insan, bir de vatanın sevdalısı olursa" onun izini her yerde arar, bulur ve sever" kelimeler hep vatan üstünedir. Üsküp de böyledir şair için:

" Gördüm güzelliğini Üsküp'te ürpererek

Sokaklarda, meydanlarda, evlerde gördüm.

Bin yıllık yüreğimle göğüs gererek

Ruhumu baktığım her yerde gördüm" (Bakiler, 1991b: 55)

Türkiye dışındaki Türklerin ihmal edilmesini; "Unuttuğumuz insanlar" diye eleştiren şair onları asla unutmaz. Şiirleri, onları anlatan kelimelerle doludur: 
"Ben Hazar Denizi'nin doğusunda doğmuşum

Hazar Denizi'nin doğusunda öleceğim.

Hazar kıyılarından Kafkas Dağları'na

Duyulmuş ağıtlar söyleyeceğim.

$\cdots$

Çaresizlikler içinde sizi düşünüyorum

Ey esir insanlar diyarında, benim esir milletim.

Ve ey Kafkas Dağlar'ı ardında

Bayraksız memleketim

Sapına kadar müslüman, sapına kadar Türk diyarı! (Bakiler, 1991b: 59)

"Bizim türkümüzde gurbet var artık

Hasret var, yürek var, toprak var balam

Gönlümüzü sımsıcak olan topraklar

Tiyan-şan, Kadır-Gan Dağları' na dek uzar

Kim demiş vatanımız Edirne'den Kars'a kadar" (Bakiler, 1991b: 60)

Şair, Ey esir insanlar diyarında, benim esir milletim" ve Bayraksız memleketim" diye üzüldüğü dış Türklerle aynı kaderi paylaşan Macarlara karşı da bir merhamet duyar.

" Kızıl emperyalizmin elleri kandaydı hep

Geçti Rus tankları üstlerinden bir anda

Şimdi insan Haklarından Macaristan'da

Bir büyük yalan kaldı.

$\cdots$

Ne güzel milletçe korkusuz, hür yaşamak

Hele yirminci yüzyılda şu feleğin işine bak

Kendi bayrağından, istiklâlinden uzak

- KIRIM, AZERBAYCAN, TÜRKiSTAN gibi Esir Macaristan kaldı" (Bakiler, 1991b: 63)

Onun şiirlerinde o toprakların ismiyle beraber sevgi, hasret, acıma ve sessiz bir isyan, daha da doğrusu feryat, çığlık ve bunları en iyi ifade eden kelimeler vardır.

"Şimdi uzaklarda kalan bir şehir vardır:

Ki sızlatır yüreğimi yıllardan beri. 
Vatan olmasına vatan Anadolucasına

Ama vatan haritamda yok yeri." (Bakiler,1991a: 59)

"Öz yurdumda yıllar yılı hasret duyarak

Mecnun gibi, Ferhat gibi bir gönül verdim.

Bir gelen olsaydı Karabağ'ımdan

Gider ayaklarına gözlerimi sürerdim." (Bakiler,1991a: 59)

Şairin gönlü oldukça zengindir. Bu gönülde Türklerin yaşadıkları bütün coğrafya yer alır. Bu gönülde Türkiye sevgisi de büyük bir yer tutar. O Türkiye'yi her şeyiyle, her haliyle sever. Onun şiirlerinde Anadolu'nun resmini ortaya koyan kelimeler vardır. Fakat şair Anadolu'nun halini istismar etmez. Gördüğü gerçeği ortaya serer. Tabii ki sevgisi ön plandadır.

"Ben kağnılarla, yaylılarla büyüdüm geldim

Çocuk yüreğimi yakan türküler dinleye dinleye...

Mahzun kağnılarla, nazlı yaylılarınla

Ve tozlu yollarında sevdim seni Türkiye!

O tezek topladığım kırlar, yaylalar...

Başına oturduğum, ekmek yediğim tandır.

Türkiyem, Anayurdum, sebebim çarem.

Taşına toprağına vurgunluğum bundandır." (Bakiler,1991b: 62)

"Bozbulanık ırmaklarında çimdin mi?

Kulak verdin mi yürekten kavala, saza?

Bir ipek seccâde üstünde gibi, huzurla...

Durdun mu toprakta namaza." (Bakiler, 1991a: 20)

Şairin şiirlerinde Anadolu'yu ve insanlarını anlatan kelimeler iki grupta toplanır. Biri güzellik diğeri ise yoksulluk, açlık, kötülük:

"Anadolu, Anadolu, ah Anadolu!..

Bir yanında güzellik, incelik ve nur...

Bir yanında, bin yıldan beridir süregelen

Toz-toprak, tezek çamur... 
İnsanlar gördüm sende: İmbikten geçmiş gibi

Yüreklerinde sıcak, misilsiz bir merhamet

İnsanlar gördüm yine: Hâin, câhil, asabî

Taş Devri'ni yaşayan bir kaba kuvvet" (Bakiler,1991a: 24)

Bâkiler çoğu zaman Anadolu insanı adına konuşur.

"Ben Anadolu'yum!.

Yıllar yılı susuz kaldım, yıllar yılı aç.

Şükrederek kaktığım sofralarımdan

Ya soğan ekmek olur yahut bulamaç.

$\cdots$

Yolsuz, okulsuz köylerim kasabalarım hâlâ

Alın terine muhtaç." (Bakiler, 1991a: 29)

"Dolaşır içimde açlardan çıplaklardan

İşsizlerden binlerce on binlerce hayalet.

$\cdots$

Asker demiş vergi demiş istemiş asırlarca

Ama karşılığında bir şey vermemiş Devlet." (Bakiler, 1991a: 31)

"Ben Numanlar köyünden Emine bacı!

Ürüzgârın erittiği karlara benziyorum." (Bakiler, 1991a: 23)

"Kılığın kıyafetin sarmadı beni

Söylediğin türküler bizim türkümüz değil." (Bakiler, 1991a: 21)

"Gecekondu: kafamızda kanlı bir bayrak..." diyen şairin dikkati kullandığı kelimelere yansımıştır:

"Kirli kirli patiskalar pencerelerde

Hasırlar, kilimler vardır yerlerde

Ocaklara konan tencerelerde,

Ya patates pişer yahut madımak" (Bakiler, 1991a: 27)

Anadolu'nun derdini dert edinen şair, bunu şiirinde kullandığı kelimelere de yansıtmıştır. Anadolu'nun en büyük dertlerinden biri olan kan davası ve bunu anlatan kelimeler de yer alır şiirlerinde. 
"Atlı candarmalara haber gitmeden

Kadınların tutturduğu ağıt bitmeden

ve daha kurumadan Receb'in kanı

Çekti hançerini Sarı İbrahim

Öldürdü babasını öldüren Süleyman'ı"

Onun şiirlerinde Anadolu'nun mezarlıkları bile yer bulur:

"Çiçeksiz, çimensiz, selvisiz, sessiz...

Bir büyük ürpertidir ruhunda varlıkları.

Bir ağıttır içimde kendimi bildim bileli.

Yoksul Anadolu mezarlıkları." (Bakiler, 1991b: 40)

Yavuz Bülent'in şiirlerinde çocukların ayrı bir yeri vardır. Çocuk sevgisi ve çocukluk günlerine duyulan hasreti dile getiren kelimelerle yüklü şiirler yazmıştır şair.

"Sevgiyle büyüyor bütün çocuklar

Ben çocuklarla büyüyorum.

Yarı çıplaksa eğer çocuklar sokaklarda

Olmaz olsun ipekler, oyuncaklar diyorum.

...

Ah çocuk sesleri, çocuk gülücükleri!...

Denizköpüğünden, ceylandan ürkek...

Sizin olsun dünyanın en güzel çiçekleri

Bir çocuğun elleri ellerimde olsun tek" (Bakiler, 1991b: 25)

Şair adeta çocuklarla özdeşleşir.

"Bir ana gülümserken yorgun ve güzel

Çırpınır yüreği bir sesle birden

Orda, bir çocuk doğar dünyamıza yeniden

Burda ben.

$\ldots$

Birdenbire uyanır bir ana uykusundan

Sapsarı bir korkuyla bakakalır nefessiz 
Orda, sabaha karşı bir çocuk ölür sessiz

Burda ben." (Bakiler, 1991b: 22-23)

*Ondaki çocuk kadrosu çok zengindir. Şairin ifadesiyle

"Gökteki yıldızlar kadar sayısız

Ah yurdumun kimsesiz ve yoksul çocukları" dediği çocukların kimi dilenci, kimi hamal, kimi yetimdir. Nane, su satar. Kimi de günahkâr ve suçludur.

Şairin şiirlerinde çocuklarla beraber en çok kullanılan kelimeler suçluluk bildiren, özür dileyen kelimelerdir.

"Ve günahkâr çocuklar, suçlu çocuklar

Mahkeme salonunda bakarım dizi dizi.

Bu suç bizim suçumuz, bu günâh bizim

Affedin bizi.

Gökteki yıldızlar kadar sayısız

Ah yurdumun kimsesiz ve yoksul çocukları

Anladım farkınız yok koparılmış başaktan!

Alın bu gözleri benden, alın bu yüreği artık.

Utanıyorum yaşamaktan." (Bakiler, 1991a: 5)

Yavuz Bülent Bakiler'in şiirlerinde en çok kullanılan kelimelerden biri türkü kelimesidir. Şair için türkü masal yerine geçmiştir. Türkü anasının sütü gibi mübarektir. Onun dili bir kınalı türküdür. Bu türküler Türk'ü söyler. Yasin Suresi gibi kutsaldır. Şairin sevdası da türkülere benzer. Illiğine, kanına işleyen türkülerdir onu bitkilerden ayıran. Anasının dilidir türkü. Onu sonsuzluğa götürür. Onun bayrağı bile tarifsiz bir türküdür. İşte " Anamın Türküsü" şairin türkü ile olan bağlarını gösteren en güzel şiirlerinden biridir.

Anamın Türküleri

Anam türkü söylerdi bana masal yerine

Hüzünlü, boynu bükük, hep Azeri türküler

Yüzüme bakamazdı, acısını anlardım.

Rüzgârlarla savrulur, yağmurlarla yağardın.

Ya yer yatağında, ya serin sofalarda 
Anamı dinlerken ağlardım.

Ben, süt gibi mübarek türkülerle büyüdüm

Bir yanım aydınlık, bir yanım gurbet." (Bakiler, 1991b: 15)

"Çocuk yüreğimi yakan türküler dinleye dinleye" büyüdüğünü belirten şair vatanını severken de türküyü ihmal etmez. "Türkiyem! Hasretim! Kınalı türkü!.." der. Anadolu ise türlü türkü doludur.

"Bin yıllık bir divan sazıdır Anadolu

Kırık bohça içinde cevheri saklı.

Binbir türküsü var köylerimizden

Binbir türküsü var telli duvaklı" (Bakiler, 1991b: 35)

Şair acılarını yüreğinde duyduğu dış Türkleri de türkü kelimesiyle sever.

"Türküler söyleyerek içimde gece, gündüz

Bir çalar saat gibi kurduğum:

Azerbaycan." (Bakiler, 1991b: 48)

"Yüzyıllar beridir Altaylardan Tuna'ya

Bizim türkülerimizdir söylenen

Konuşulan dil, bizim dilimizdir" (Bakiler, 1991a: 61)

"Boynu bükük türkülerde güzelim." (Bakiler, 1991a: 61)

Şair Türkiye ile dış Türkleri "Güzelim türküleri türkülerimiz gibidir" diyerek birliği vurgulamaya çalışır. Fakat yine de Türk'ün türküsünde gurbet, hasret vardır.

"Bizim türkümüzde gurbet var artık

Hasret var, yürek var, toprak var balam" (Bakiler, 1991a: 60)

Şair türkü kelimesini öylesine çok sever ve ona öylesine değişik anlamlar yükler ki bazen hayrete düşersiniz.

"Çirkinim.

Usandım tek başına türküler çağırmaktan

Biliyorum güzel değil gözlerim, dudaklarım

İçimizden çıkıp gitsem bir gün diyorum

Başladığım bütün türküler yarım

Öyle bakmayın yüzüme kahroluyorum. 
Türküler unutturmaz çirkinliğimi... (Bakiler, 1991c: 37)

Şair, bir güzelin gözlerini rahatça türküye benzetebilir.

"Türkülü gözlerin ıslak ıslaktı" (Bakiler, 1991c: 11)

"Japon türkülerine benziyordu gözlerin

Sen Japon türkülerini bilmezsin." (Bakiler, 1991c: 20)

"Kızımın türkü gibi güzel Aybala adında" (Bakiler, 1991b: 49)

İstanbul'u bile türkülerde sever.

"Türkülerde yağmur yağmur Üsküdar

Dualarda sımsıcak Eyüp Sultan" (Bakiler, 1991c: 17)

"Ellerin, Türküler, uykular kadar güzel" (Bakiler, 1991a: 44)

"Türküler gibi içten, sıcak halleri vardı

Kızlar ki ince, uzun ve mahzun kuğulardı" (Bakiler, 1991a: 53)

Şairin türkü kelimesine bu kadar farklı anlamlar yüklemesi, türkülerle büyümesinden, tarihi yönden, coğrafi yönden olmalıdır. Annesi Azerbaycan'a olan hasretini türkülerle dile getirmiştir. Anadolu insanı ölüsüne türküyle ağlamış, düğününde ise türküyle oynamıştır. Şair bu yönüyle tam bir Anadolu insanıdır.

Şair doğduğu şehri ve insanlarını da yansıtır şiirlerinde.

"Beni bir eski Sivas evine bir gün eğer

Götürseniz, çocuklaşır, şaşarım.

Eşiklerini bile öperim birer birer

Sanki bin yıl yaşarım. " (Bakiler, 1991b: 31)

"Halayların, türkülerin çağırır beni uzaktan

Yüreğim hep Mısmıl Irmak gibi tertemiz...

Nerde Çifte Minareniz, Gök Medrese'miz?

Sımsıcak dualarla maziyi aran şehir." (Bakiler, 1991a: 35)

Şair, Sivas insanının yoksulluğunu yüreğinde duyar ve duyurur. Bunu yaparken de yöre insanının kullandığı kelimeleri seçer.

"Düşün! Nasıl doyarukh bir sofrada on gaşuklu

Nasıl ısınurukh bu Suvaz ayazında 
Ev desen ev dööül oturduğumuz

Gışın ölü damı, yazın alaçukh" (Bakiler, 1991b: 33)

"Sivas'ta Ulu Câmi avlusunda yoksul çocuklar

Yalvaran gözlerle etrafa baka baka

Açıyor küçücük esmer avuçlarını:

- Emmilerim sadaka! Emmilerim sadaka!" (Bakiler, 1991a: 9)

Geleneklerine bağlı, muhafazakâr bir ailede yetişen şairin dini inancı da tamdır. Dini inançlarını büyük bir huzurla yaşayan annesi ve namazları insanı rahatlatan "serinlik, huzur, aydınlık, ince mübarek nur, bereket, iffet, merhamet gibi kelimelerle anlatılır.

"Anam, namaza durur günde beş vakit

Bir serinlik duyarız. Ondaki büyük huzurdan.

Aydınlanır içimiz, odalarımız

Yüzündeki ince, mübarek nurdan

$\cdots$

Ne şikâyet, ne kin, ne şüphe biraz

Sessizliği, yüreğinin niyazındandır

Elinin bereketi, iffeti, merhameti...

Kıldığı sonsuzluk namazındandır." (Bakiler, 1991b: 18-19)

İstanbul da onun şiirlerinde kendine yer bulur. Şairin şehre bakışı anasının namazına bakışına benzer. İstanbul da serin, şamdanlar gibi aydınlıktır. Özellikle minarelerini ince kaleme benzetmesi sevgisindendir. Şiirlerinde İstanbul'un dini mekânlarına da dikkat çekmiştir.

"Can evimden baktım sana İstanbul!

Rüzgârların anamın duası kadar serin.

Beyaz şamdanlar gibi yükseliyordu

Ince kalem minarelerin.

$\cdots$

Bayezid Camii'nde bir namaz kıldım

Safların ardında garipsi, mahzun.

Sen bin yaşa sımsıcak dualarda

Ey destan şehri Yurdumuzun." (Bakiler, 1991c: 16-17) 


\section{Nazım Hikmet ve Yavuz Bülent'in Dil Politikalarının Karşılaştırılması}

Her iki şairin şiirlerinde kullandıkları kelime kadrosunda büyük farklılık bulunmaktadır. Bu farklııklar onların siyasi düşünce ve yetiştikleri ortam ayrılığından kaynaklanmaktadır. Şairlerin kelime kadrosundaki en büyük farkı oluşturan sebep ise siyasi düşünce ayrılığıdır.

"Ben ki, herhangi bir proleter şairiyim" diyen Nazım Hikmet, herhangi bir komünist şairin işlediği konuları ve o ideolojinin kullandığı kelime ve kavramları kullanmıştır. Düşüncesini en iyi yansıtan kelimeleri özenle seçmiştir. 1950'de hapisten çıktıktan sonra gittiği Moskova ve Doğu Bloğu ülkeleri, şehirleri ve insanları şiirlerinde resmigeçit yaparlar. Yine onun şiirlerinde Amerika, İngiltere, Almanya, banka, emperyalizmin zulmü, kötülüğü, haksızlığı simgeleyen kelimelerdir. Buna karşılık 1 Mayıs, Lenin, Engels, gibi kelimeler de özgürlüğün, ekmeğin, dünya kardeşliğinin, eşitliğin adı olmuştur. Denilebilir ki Nazım, Moskova Komünist Partisinin bir memuru gibi davranmış bunu da aynen şiirlerine yansıtmıştır.

"Marks'ı, Engels'i, Lenin'i sevdiğim gibi

Sevdiğiniz gibi

Aynı muhabbetle, aynı hürmetle seviyorum"

Yukarıdaki şiirde yücelttiği Stalin'i daha sonra Komünist partinin emriyle "Kalktı göğsümüzden baskısı, binlerce ton taşın, tuncun, alçının ve kâğıdın" diyerek yermekten çekinmemiştir. Zaten bir şiirinde o proleter şairlerin nasıl şiir yazdıklarını, neyin çı̆̆ırtkanlıklarını yaptıklarını, kendisi anlatır.

"Biz proleter şairleri.

Elimizde badana fırçaları önümüzde kovalar

Amele kahvelerine destan

Kızıl bayraklara şiar

Fabrika duvarlarına ilan yazıyorduk.

Size istismarsız

Burjuvasız, hükümdarsız

Bir cemiyet veren sınıfımızın

Sesi sıtma görmemiş çığırtkanlarıydık

$\mathrm{Ve}$

Daima öyle

Kaldık." (Ran, 1995h: 171) 
Nazım Hikmet, çoğu şiirlerinde dünya görüşünü yansıtan kelimeleri sık sık ve arka arkaya kullanmış, bu tarz şiirlerinde çoğu zaman şiiriyeti geri plana itmiştir.

Ahmet Kabaklı'ın "Arif Nihat Asya üstadımızın temsilcisi olduğu milli, İslâmi, tarihi bedii şiir tarzı, Yavuz Bülent ile genç ve güçlü bir şair kazanmış oluyor." dediği Yavuz Bülent, şiirlerinde bu görüşlerini aksettiren kelimeleri ustalıkla kullanmıştır. Onun görüşlerini yansıtan kelimeleri iki bölümde incelemek gerekir. Birinci grubu dış Türkler ve onlarla ilgili kelimeler oluşturur. "Türkistan ve Azerbaycan kendimi bildim bileli benim kara sevdandır" diyen şair şiirlerinde dış Türklerin durumunu anlatan kelimeleri ve onlara olan sevgisini bildiren kelimeleri her fırsatta kullanır.

Şair için Türk vatanı Edirne'den Kars'a kadar değildir. Tiyan-Şan, Kadır-Gan Dağlarına dek uzar. Dış Türkleri anlatan kelimelerin önünde de genellikle " Boynu bükük türkülerde güzelim Azerbaycan", " Bir kanlı ağıt söylenir şimdi Kırım'da", "Ulu Türkistan'a yandım" gibi sevgi ve merhamet bildiren sıfatların bulunması; şairin bu konudaki duyarlılığını göstermektedir.

İkinci grubu Anadolu ve Anadolu insanını anlatan kelimeler oluşturur. Bir yanda Anadolu'nun bitmez tükenmez dertlerini anlatan kelimeler bir yandan da bitmez tükenmez güzelliklerini, zenginliklerini anlatan kelimeler. Şair bağrından çıktığı Anadolu'yu ve insanını iyi tanır ve çoğu zaman da onun adına konuşur.

"Ben Anadolu'yum, acilı, mahzun.

Bende bitmez tükenmez dert kulaç kulaç"

"Anadolu, Anadolu, ah Anadolu!..." diye onun çı̆̆lı̆̆ı olur. Seçtiği kelimeler de bu türden kelimelerdir. Dolayısıyla dünya görüşleri farklı iki şair, bu farklarını kelimelerine de yansıtmışlardır. Nazım Hikmet'in şiirlerinde dış Türkler (bir iki şiirinde yer ismi dışında) geçmezken, Yavuz Bülent'in şiirlerinde de Lenin, Marks, yoldaş, Amerikan, İngiliz düşmanlığı, Doğu Bloku ülkeleri gibi isimler geçmez. Buradan hareketle 'şairler dünya görüşlerini kelimelerine yansıtırlar' diyebileceğimiz gibi 'şairlerin kullandığı kelimelere bakarak onların dünya görüşlerini tespit etmek mümkündür' sonucuna varabiliriz. Çünkü dünya görüşü bireyin dil politikasının belirlenmesinde önemli bir ölçüdür.

Her iki şair farklı çevrelerde ve farklı aile ortamında yetişmişlerdir. Bu da onların şiirlerinde kullandıkları kelime seçimini etkilemiştir. Nazım Hikmet'in çocukluğu ve tahsilinin ilk dönemi İstanbul'da geçmiş, daha çok Mevlevi tarikatı mensubu dedesinin terbiyesinde büyümüştür. Sıkıntılı bir aile ortamında geçen günlerden sonra gittiği Moskova onun hayatını derinden etkilemiştir. İlk dönemki duyarlılıkların yerini komünizm almıştır. Bu dönemlerde yazdığı şiirlerinde kullandığı kelimelere bakınca bu açıkça görülebilir. Onun şiirlerinde kullandığı kelimelere bakarak hayatının dönemlerini veya hayatının dönemlerine bakarak şiirlerinde kullandığı kelimeleri tespit etmek mümkündür. 
On dokuz yaşına kadar şiirlerinde kullandığı kelimeler dini ve milli duyguları ifade ederken sonrasında bunlarda azalma görülmektedir. On dokuz yaşı onun için dönüm noktası olmuştur. Bu yaş onun komünizmi tanıdığı ve Moskova'ya gittiği yaştır. Bu yaşından 1950'ye kadarki dönemde yazdığı şiirlerinde hapishane hayatını yansıtan kelimeler ağırlıktadır. 1950'den sonra yazdığı şiirlerde ise Moskova ve Doğu bloğu ülkelerine yaptıkları gezi ve incelemelerini yansıtan kelimeler vardır. Şair bulunduğu ortamı ve bilhassa yaptığı gezileri diline yansıtmış, gezdiği yerleri ve oralarda edindiği intibaları anlatan şiirler yazmıştır. Nazım Hikmet Romanya, Bulgaristan gibi ülkelere yaptığı gezileri anlatan şiirlerinde, Anadolu'yu da özlemle anmış ve ikisini karşılaştırma gereği duymuştur. Bu konuda M. Kaplan'ın tespiti ilginçtir. "Türkiye'de doğan Nazım'ın tıpkı Türkiye'de doğan, sonra vatana ihanetlerinden dolayı Türkiye dışına çıkarılan Rumlar ve Ermeniler gibi Türkiye topraklarını, hatta Türk halkını sevmesi, onun Moskova emrinde, Türkçeyi çok iyi kullanan, kökü Polonyalı bir şair olduğu gerçeğini yok etmez" (Kaplan, 1980: 362).

Nazım Hikmet Sovyetler Birliğindeki Türk topraklarını da gezmiştir ama şiirlerinde onlardan hiç bahsetmemesi dikkat çekicidir. Şiirlerinde Japon çocuğa ve Kalküta'ya üzülen şairin Kırım Türklerinin vatanından sürülmesine seyirci kalması ancak ideolojisiyle açıklanabilir. Denilebilir ki o gezdiği, bulunduğu yerlere de ideoloji ile bakmıştır.

Yavuz Bülent ise Anadolu'nun ortasında milli ve manevi duygulara bağlı gelenekçi, muhafazakâr bir ortamda; Sivas'ta, Azerbaycan'ın Karabağ şehrinden göç etmiş bir ailede yetişmiştir. Yetiştiği çevrenin her şeyini sevgiyle kucaklayan şair, bunu kelimelerine de yansıtmıştır. Şiirlerindeki dış Türklerle ilgili kelimeler yetiştiği ortamda sevgi ve hasretle ruhuna işlenmiştir. $O$ annesinden ninni yerine Azeri türküsü dinlemiştir. Babasının elinde de Türkistan'ın durumunu anlatan kitaplar görmüştür. Daha da önemlisi babası tarafından böyle yetiştirilmeye çalışılmış, öğrenciliği böyle düşünen kimselerin yanında (Osman Yüksel Serdengeçti) geçmiştir. Sıcak, huzur dolu bu aile ortamı şairin şiirlerine de yansımıştır. Bu nedenle şiirlerinde her şeye karşı büyük bir sevgi bildiren kelimeler vardır. Bu yüzden o Nazım gibi haykırmaz içten içe yanar, ağlar. Nazım'ın şiirlerinde bağırış, çağırış, kavga Bakilerin şiirinde ise sessizlik, sessiz çığlık ve bunları yansıtan kelimeler vardır.

Şairlerin dil politikalarını belirleyen bir başka faktör de yaşadıkları ve gezip gördükleri yerlerdir. Doğu bloğunu gezen Nazım Hikmet'in şiirleri bu gezinin izleriyle, Türkistan'ı gezen Bâkiler'in şiirleri de Türkistan'ın izleriyle doludur. Ancak sanatçılar gezdikleri yerlere bakarken de ideolojiktir. Nazım Hikmet'e göre Macaristan özgürlüğün timsalidir. Yavuz Bülent'e göre ise Macaristan esirdir. Tıpkı Azerbaycan, Kırım ve Türkistan gibi.

Demek ki şairlerin yetiştikleri ortam, gezdikleri, gördükleri yerler kullandıkları kelimelere yansımaktadır. Her iki şairde de bunu görürüz. Ancak bizce çok önemli olan bir husus da her iki şairin de 
gezdikleri yerlere kendi görüşleri doğrultusunda bakmış olmalarıdır. Nazım, Macaristan'ın komünizmini överken, ona gıpta ile bakıp “ Anadolu'm ne zaman senin gibi olacak “ derken Bakiler Macaristan'a tıpkı Azerbaycan'a, Kırım'a baktığı gibi bakar ve Macaristan'ı "esir" kelimesiyle tanımlar.

Her ne kadar birbirinden farklı ortamlara yetişseler de birbirinden farklı siyasi düşüncelere sahip olsalar da şair olmaları ve aynı dille yazmaları onların ortak kelimeleri kullanmalarını da gerektirmiştir. Âşık Veysel'in "Türk'üz türkü çağırırız" dediği gibi Yavuz Bülent sazıyla türkü çağırmasa bile şiirleriyle türkü söylemiştir. Onda türkü, anne sütü gibi vazgeçilmez bir ihtiyaç, Yasin gibi kutsal, bayrak kadar yüce, annesinin dili kadar sıcaktır. Ama onda türkü hep gurbeti, acıyı, yakarışı anlatır. Şairin de dediği gibi türkü onun kanına, iliğine işlemiştir. Anadolu'yu Azerbaycan'ı Türkistan'ı, Kırım'ı anlatır türküler. Ve türkülerimiz birbirine benzer.

Nazım Hikmet de türkü kelimesine özel anlamlar yüklemiştir, türkü kelimesi daha çok Anadolu hasretini ifade etmek için kullanılmıştır. Ancak şair türkü kelimesini görüşünü yansıtmak amacıyla da kullanmıştır. Türkü onda Yavuz Bülent'ten farklı olarak bütün insanlık için kullanılmıştır:

"İnsanların türküleri, kendilerinden güzel,

Türküleri anladım, hangi dilden söylenirse söylensin" diyen şairin dizelerinde türkü kavramına yüklediği dünya kardeşliği düşüncesi açıkça görülür. Şair evrenselliğin peşindedir.

Her iki şair de çocuklara özel ilgi göstermişler ve şiirlerinde çocuk sevgisini işlemişlerdir. Ancak Bakilerin şiirinde geçen çocuk, Sivas'taki hamal, boyacı, yoksul çocuktur. Buradan hareketle bütün kimsesiz çocukları içine alır. Nazım Hikmet'in şiirlerindeki çocuk ise kapitalizmin zulmüne uğrayan çocuktur. Ya Japonya'da atom bombasında kimsesiz kalan çocuk ya da Kalküta'da İngiliz polisi tarafından ırmağa atılan çocuktur. Kimi zaman da Portsaidli boyacı çocuktur. Nazım Hikmet'in çocuğu seçmesi şair duyarlılı̆̆ını gösterirken; kapitalizmin karşısında ezilen, hakları ellerinden alınan çocuğu kullanması dünya görüşünü benimsetmek içindir. O insanların çocuklara karşı olan duyarlılıklarını kullanarak politikasını pekiştirmiştir.

Herk iki şairin çocuklara olan ilgisi şair duyarlılığıyla açıklanabilir. Nazım Hikmet’te çocuk daha çok evrensel açıdan ele alınırken Bakiler daha çok millî yönden ele alınır.

Her iki şair aşk ve sevda üzerine yazdıkları şiirlerde ortak kelimeler kullanmışlardır. Bu durum bu duygunun evrenselliğiyle açıklanabilir. Aynı şekilde Anadolu, Anadolu insanı, memleket gibi temaları ele aldıkları şiirlerinde de ortak kelimeler görülür.

Dünya görüşleri birbirinden farklı olan iki şairin dil politikaları da birbirinden farklıdır. Bu farkı ortaya çıkaran en önemli sebep ideolojilerinin farklı olmasıdır. Her iki şair de kendi düşüncelerini yansıtan kelimeleri özellikle kullanmışlar veya kelimelere düşüncelerini yansıtan kavramlar yüklemişlerdir. 
Türkçe yazan her iki şairin şiirlerinde ortak olan pek çok kavram vardır. Bu elbette olacaktır. Önemli olan şairlerin düşüncelerini yansıtmak için uç kelimeleri kullanmış olmaları veya onlara uç anlamlar yüklemeleridir. Bu uç kelimelere bakarak şairlerin dünya görüşlerini belirlemek mümkündür. Başka deyişle sanatçıların dünya görüşlerini kullandıkları kelimelerde aranabilir.

\section{Kaynakça}

Bakiler, Y. B. (1991a). Duvak, İstanbul: Polat Ofset Yayınları

Bakiler, Y. B. (1991b). Seninle. İstanbul: Türk Edebiyatı Vakfı Yayınları

Bakiler, Y. B. (1991c). Yalnızlık. İstanbul: Polat Ofset Yayınları

Bakiler, Y. B. (1992). Türkistan Türkistan. İstanbul: Polat Ofset

Kabaklı, A. (2000). Türk Edebiyatı, C. IV. İstanbul: Türk Edebiyatı Vakfı Yayınları

Kaplan, M. (1980). Şiir tahlilleri II (Cumhuriyet devri Türk şiiri). İstanbul: Dergâh Yayınları

Korkmaz, Z.(1995). Türk Dili üzerine araştırmalar, Birinci Cilt , Ankara : Türk Dil Kurumu Yayınları

Özdemir, E. (1973). Dil ve yazar. Ankara: Türk Dil Kurumu Yayınları

Ran, N. H. (1995a). 1.Kitap. 835 satır. İstanbul: Adam Yayınları

Ran, N. H. (1995b). 2. Kitap, Benerci kendini niçin öldürdü? İstanbul: Adam Yayınları

Ran, N. H. (1995c). 3. Kitap, Kuvayı-i Milliye. İstanbul: Adam Yayınları

Ran, N. H. (1995d). 4. Kitap, Yatar Bursa Kalesinde. İstanbul: Adam Yayınları

Ran, N. H. (1995e). 5. Kitap, Memleketimden insan manzaraları. İstanbul: Adam Yayınları

Ran, N. H. (1995f). 6. Kitap, Yeni Şiirler. İstanbul: Adam Yayınları

Ran, N. H. (1995g). 7. Kitap, Son şiirler. İstanbul: Adam Yayınları

Ran, N. H. (1995h). 8. Kitap, Ilk şiirler. İstanbul: Adam Yayınları

Timurtaş, F.K. (1997). Sanat-edebiyat dünyasından (Haz. Özkan, M.) İstanbul: Alfa Yayınları

Uygur, N. (2001). Dilin gücü. İstanbul: Yapı Kredi Yayınları 